
\title{
25 Research Soure \\ The Difference of ACE and ACE2 Gene Expression in Patients With Acute Aortic Dissection and Coronary Heart Disease
}

Yang Li

Chengdu Second People's Hospital

Long Mao

Chengdu Second People's Hospital

Zongwei Xiao

Chengdu Second People's Hospital

Sandeep Bhushan ( $\nabla$ dr.sandeep07@yahoo.com )

Chengdu Second People's Hospital https://orcid.org/0000-0002-7505-3831

Research article

Keywords: angiotensin converting enzyme, rennin-angiotensin system, matrix metalloproteinases, matrix metalloproteinases

Posted Date: April 21st, 2021

DOl: https://doi.org/10.21203/rs.3.rs-419515/v1

License: (c) (i) This work is licensed under a Creative Commons Attribution 4.0 International License. Read Full License 


\section{Abstract}

\section{Background}

To explore whether there is a difference in the expression of ACE and ACE2 genes in patients with acute $A D$ and $C H D$.

\section{Methods}

Blood samples from 68 patients, including 34 cases of acute AD (including Stanford type A and B), 21 cases of CHD, and 13 cases of control group. $2 \mathrm{ml}$ of venous blood is submitted for plasma ACE concentration. The arterial wall tissue was taken during the operation for mRNA detection.

Results

The ACE concentration in the AD group was $(17.9 \pm 7.9) \mathrm{U} / \mathrm{L}$, in the CHD group was $(33.5 \pm 8.1) \mathrm{U} / \mathrm{L}$, and the ACE concentration in the control group was $(38.4) \pm 4.8) \mathrm{U} / \mathrm{L}$, statistically significant $(P<0.05)$. The expression of ACE gene in the AD group was ( $0.2265 \pm 0.3783)$; the expression in the CHD group was (7.085 $7 \pm 7.6929)$, with significant $(P<0.05)$. The expression of ACE2 gene in the AD group was $(0.766$ $2 \pm 0.8586)$; in the CHD group was $(9.6127 \pm 11.5426)$, and the difference was significant $(P<0.05)$. The expression of the ratio of ACE / ACE2 in the AD group was $(0.4138 \pm 0.448)$; the expression in the CHD group was $(0.8111 \pm 0.2563)$, the difference was statistically significant $(P<0.001)$.

Conclusion

Plasma ACE concentration, ACE and ACE2 gene expression are significantly reduced in acute AD. The imbalance of ACE and ACE2 expression may be involved in the pathogenesis of AD.

\section{Introduction}

Although the overall incidence of aortic dissection is not high, it has been increasing in recent years. When aortic dissection occurs(AD), its mortality rate is relatively high, and it is a serious clinical emergency that threatens the life of patients [1]. High-risk factors that cause aortic dissection include hypertension, atherosclerosis, dyslipidemia, smoking, genetic factors, trauma, etc. Aortic aneurysm is also a cause of active artery dissection. However, hypertension, atherosclerosis, and aneurysms are not uncommon in clinical practice. Most of them have not been transformed into aortic dissection, and aortic dissection has a certain relationship with heredity [2]. Therefore, we imagine that some genes may be expressed in these diseases and there are differences that lead to aortic dissection in some patients.

The rennin-angiotensin system (RAS) is an important endocrine regulation system of the body, which plays an important role in regulating the occurrence and development of hypertension, atherosclerosis, and water and sodium retention [3]. Angiotensin converting enzyme (ACE) and angiotensin converting enzyme 2 (angiotensin converting enzyme2, ACE2) works together in the RAS system and antagonize 
each other. At present, domestic and foreign studies have found that both ACE and ACE2 are related to the cardiovascular system [5]. Diseases such as hypertension, coronary heart disease(CHD), heart failure, ventricular hypertrophy, diabetes, metabolic syndrome and other diseases are related. Therefore, we completed this experiment to understand whether ACE, ACE2 and their genes play a role in the occurrence and development of aortic dissection.

\section{Methods}

Clinical data: The experiment is divided into AD group, CHD group and control group. The control group was normal adults without cardiovascular disease. A total of 68 blood samples were collected from March 2011 to October 2012, including 34 cases of acute aortic dissection, 21 cases of coronary heart disease, and 13 cases of the control group; there was a history of taking ACEI and ARB preparations and patients with Marfan syndrome were not admitted this experiment. The specific clinical data of the patients are shown in (Table 1).

All patients received $2 \mathrm{ml}$ of venous blood on an empty stomach in the early morning of the second day after the hospital, and sent for plasma ACE concentration.

During the operation, the arterial wall tissue of the above-mentioned patients was taken during the operation, put in a liquid nitrogen tank, and then transferred to $-70{ }^{\circ} \mathrm{C}$ refrigerators for storage, and then used for mRNA detection; performing thoracotomy and obtaining aortic wall tissue for aortic dissection 12 Cases, 16 cases of coronary heart disease. The reasons for not obtaining the aortic wall tissue were: 9 cases in the aortic dissection group were treated with intermediary, 8 cases were not in the surgical treatment, 5 cases died before the operation; 2 cases in the coronary heart disease group were treated with non-surgical treatment, and 3 cases had too little aortic wall tissue taken during the operation and were discarded.

Detection of the expression of ACE and ACE2mRNA in the tissues: The total RNA of the tissues was extracted by the Trizol method, and the extracted total RNA samples were reverse transcribed into cDNA by reverse transcriptase. Use BI0.RAD's iscript TM cDNA synthesis Kit to perform amplification on a polymerase chain reaction (PCR) machine. After completion, store the cDNA samples in a refrigerator at $-20{ }^{\circ} \mathrm{C}$ for later use for subsequent real-time PCR detection. The reaction conditions are: $95{ }^{\circ} \mathrm{C}$ predenaturation $180 \mathrm{~s} \rightarrow$ then $95^{\circ} \mathrm{C} 10 \mathrm{~s}, 59{ }^{\circ} \mathrm{C} 10 \mathrm{~s}, 72{ }^{\circ} \mathrm{C} 10$ s cycle 40 times $\rightarrow$ finally from $65^{\circ} \mathrm{C}$ by $0.5^{\circ} \mathrm{C}$ / $\mathrm{s}$ increment to $95^{\circ} \mathrm{C}$ to end the reaction. (Table-2)

Statistical analysis: The results are expressed as mean \pm standard deviation, and SPSS 20.0 is used for statistics. The difference in the compositional ratio of gender, history of hypertension and history of diabetes in each group was tested by chi-square test. When the frequency of each group was less than 5 , the exact probability method was used. The difference of serum ACE concentration, ACE mRNA expression and ACE2 mRNA expression between each group was compared by single Factor analysis of variance; $P<0.05$ is statistically significant. 


\section{Results}

1. Comparison of serum ACE concentration among patients: The ACE concentration in the aortic dissection group was $(17.9 \pm 7.9) \mathrm{U} / \mathrm{L}$, the ACE concentration in the coronary heart disease group was $(33.5 \pm 8.1) \mathrm{U} / \mathrm{L}$, and the ACE concentration in the control group was $(38.4 \pm 4$. 8) $\mathrm{U} / \mathrm{L}$. The comparison between the aortic dissection group and the coronary heart disease group was $\mathrm{P}<001$ and the comparison between the coronary heart disease and the normal group was P 30.05 and the difference between the groups were statistically significant.

2. Results of ACE expression in patient tissues between groups: The expression of ACE in the aortic dissection group was $(0.227 \pm 0.378)$; the expression in the coronary heart disease group was $(7.086$ $\pm 7.693), P<0.05$. The difference between the groups was statistically significant.

3. ACE2 expression results in patient tissues between groups: The expression of ACE2 in the aortic dissection group was $(0.766 \pm 0.859)$; the expression in the coronary heart disease group was $(9.613$ $\pm 11.543), \mathrm{P}<0.05$. The difference between the groups was statistically significant. Comparison of ACE/ACE2 ratios in patient tissues between groups The expression of the ACE/ACE2 ratio in the aortic dissection group was $0.414 \pm 0.449$ ); the expression in the coronary heart disease group was $(0.811 \pm 0.256)$. The aortic dissection group was significantly lower than the coronary heart disease group, and it was statistically significant $(P<0.05)$.

\section{Discussion}

ACE is a zinc-containing metalloprotease, which mainly exists in the vasculature. ACE transforms inactive Ang I into vasoconstrictor Ang II [1]. The latter acts on AT1 to constrict blood vessels and stimulate aldosterone secretion, leading to increased blood pressure. At the same time, ACE can also hydrolyze bradykinin to make it Inactivation, and bradykinin can release N0, prostaglandin and other endothelial cytokines to relax blood vessels and inhibit the proliferation of vascular smooth muscle cells. In addition, ACE can also hydrolyze many other vasoactive peptides. Studies have shown that Ang II can cause the production of superoxide anion (02.), nitric oxide (NO.), and hydrogen peroxide $\left(\mathrm{H}_{2} \mathrm{O}_{2}\right)$, produce a strong vasoconstrictor effect, induce a variety of inflammatory factors, and activate macrophages and monomers. Nuclear cells induce inflammation; at the same time, they induce and promote vascular smooth muscle proliferation and vascular remodeling, leading to vascular wall damage and promoting atherosclerosis. In addition, inflammatory response can activate reactive oxygen species and cause oxidative stress in tissues, and oxidative stress plays an important role in cardiovascular diseases [2-3], including atherosclerosis, hypertension, coronary heart disease, etc.; At the same time, reactive oxygen species can activate MMPs (matrix metalloproteinases). MMP.1, MMP.2, and MMP.9 have been confirmed in a number of experiments to be related to the occurrence of aortic dissection/aneurysm [4-5]. Therefore, Angll may promote the occurrence of aortic dissection [6], and studies have shown that the RAS system plays a role in the occurrence of abdominal aortic aneurysm [7]. Although experiments found that ACE activity in cardiovascular diseases such as heart failure, hypertension, and angina pectoris was significantly increased in the disease group [8-10], the detection of peripheral venous blood ACE 
concentration in this experiment showed contradictory results. The concentration of ACE in the aortic dissection group decreased and was statistically significant $(P<0.05)$; while the concentration of ACE in the coronary heart disease group and the control group did not change significantly.

This change is consistent with the expression of ACE mRNA in the ascending aorta wall. The expression of ACE mRNA in the aortic dissection group is lower than that in the coronary heart disease group, and there is a statistical difference between the two groups $(P<0.05)$. We speculate that the reasons for this phenomenon may be: (1) Changes in the body after aortic dissection lead to a decrease in ACE. ACE can be converted into Angll by acting on Ang I, and Ang II can also regulate ACE. Current studies have shown that Angll can up-regulate ACE through AT1. ERK (extracellular signal regulation) / p38 MAP (mitogenactivated protein) kinase pathway at the same time, ACE2 is reduced [11-12]. (2) Aortic dissection occurs after ACE decreases. ACE transforms Angl into Angll and produces vasoconstriction. When ACE is excessively reduced, the vasoconstriction effect on blood vessels decreases, which may lead to changes in the tension of the aortic wall, and this change in tension, may lead to aortic dissection to some extent However, the number of cases in this experiment is small, and further sample studies are needed to confirm whether this relationship exists. In addition, the patients in the aortic dissection group in this experiment are all acute aortic dissections. Whether there are similar results in chronic aortic dissection patients is not known, and further experimental verification is needed.

In the past, it was thought that only the ACE Ang II. AT1 axis existed in the RAs system, but in 2000 Donoghue [13] and Tipnis et al. [14] respectively confirmed that there is another homologous substance in ACE, that is, angiotensin-converting enzyme 2 (ACE2). It is found that there is another branch system in the RAS system: ACE2.Ang (1.7).Mas axis. Like ACE, ACE2 is also a zinc-containing metalloprotease. Studies have shown that the metal catalytic region of ACE2 is $42 \%$ identical to ACE [13]. The gene encoding ACE2 contains 18 exons and the gene encoding ACE contains The 17 exons are similar [14]. The distribution of ACE2 in the human body is not as widespread as that of ACE. It is mainly distributed in the heart, kidney, testis, lung, arteries, veins, brain and other tissues. Among them, the ileum is the most distributed, and it is also more distributed in the cardiac vascular endothelial cells and kidney tissues [15]. ACE2 can decompose Angll into Ang (I-7). In addition, ACE2 can also directly act on Ang-1I to decompose it into Ang (I-9). Ang (I.9) is then decomposed into Ang (I-9) under the action of ACE. L-7), meanwhile, the efficiency of ACE2 to decompose Angll is 400 times that of Angl [16]. The physiological functions of Ang (1-7) are mainly to relax blood vessels, lower blood pressure, improve coronary perfusion and endothelial function, inhibit the hypertrophy of myocardial cells, inhibit the proliferation of myocardial fibroblasts, and also have inhibitory effects on vascular smooth muscle cells. In vitro experiments have also confirmed that ACE2 can decompose other vasoactive peptide terminal amino acids, including exercise vasopressin, bradykinin desarginine, etc [17], and ACE2 can also catalyze the decomposition of the activities of aPelin.13 and apel16, and aPelin-13 can cause ionization. With the contraction of the coronary arteries, ACE2 can also stimulate the body to produce vasodilators such as NO, prostaglandins, and bradykinin[18]. Because the physiological effect of ACE2 is opposite to that of ACE, many domestic and foreign studies have suggested that ACE2 can stabilize atherosclerotic plaques, reduce platelet adhesion, anti-thrombosis, reduce inflammation, promote myocardial remodeling, and lower blood 
pressure, etc. [19] Therefore, the current literature generally believes that ACE2 plays a protective role in cardiovascular disease. In this experiment, the expression of ACE2 mRNA in the ascending aorta wall was observed. The expression of ACE in the aortic dissection group was lower, which confirmed that ACE2 may have a protective effect in the occurrence of aortic dissection. However, this experiment has no results of the expression of ACE and ACE2 in the ascending aorta wall of normal people, and its expression in normal people is still unknown. In addition, studies have shown that the imbalance of the ratio of ACE and ACE2 has a certain relationship with the occurrence of cardiovascular disease [8]. In this experiment, we also observed the difference between the ratio of ACE and ACE2 among the groups. The results showed that the ratio of ACE/ACE2 was in the aortic dissection. In the coronary heart disease group and the coronary heart disease group, they were $(0.414 \pm 0.449)$ and $(0.811 \pm 0.256)$. Statistical analysis showed that the difference in the proportion of the aortic dissection group and the coronary heart disease group was statistically significant $(P<0.05)$, suggesting that the imbalance of the proportion of ACE and ACE2 may have a certain relationship with the occurrence of different diseases. In summary, this experiment showed that plasma ACE concentration, ACE and ACE2 gene expression were significantly reduced in aortic dissection, providing evidence for the role of the RAS system in the occurrence of aortic dissection. However, how the expression of ACE and ACE2 changes during the pathogenesis of aortic dissection is still unknown, and further studies are needed to confirm it.

\section{Conclusion}

This experiment showed that plasma ACE concentration, ACE and ACE2 gene expression were significantly reduced in aortic dissection, providing evidence for the role of the RAS system in the occurrence of aortic dissection. However, how the expression of ACE and ACE2 changes during the pathogenesis of aortic dissection is still unknown, and further studies are needed to confirm it.

\section{Abbreviations}

AD: aortic dissection, ACE: angiotensin converting enzyme, CHD: coronary heart disease, MMPs: matrix metalloproteinases, PCR: matrix metalloproteinases RAS: rennin-angiotensin system

\section{Declarations}

Acknowledgement: All authors contribute equally to this manuscript.

\section{Declarations:}

Ethics approval and consent to participate: The protocol was approved by the Chengdu Second People's

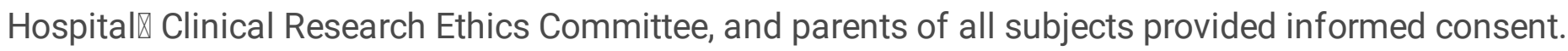

Consent for publication: Not applicable

Availability of data and materials: Not applicable, Please contact author for data requests 
Statement of competing interests: "The authors declare that they have no competing interests."

Funding: Not applicable

Acknowledgement: All authors contribute equally to this manuscript.

\section{Author Contributions:}

$\mathrm{YL}^{1}$ : Concept/Design, Data analysis, drafting article, Critical revision of article, Approval of article.

$\mathrm{LM}^{1}$ : Concept/Design, Interpretation, Critical revision of article, Approval of article.

ZX1: Concept/Design, Data analysis, drafting article, Critical revision of article, Approval of article.

$\mathrm{BS}^{1}$ : Corresponding author, Concept/Design, Data analysis/interpretation, drafting article, Critical revision of article, Approval of article, Statistics, Funding, Data collection.

\section{References}

1. Li Y, Hu J, Qian H, et al. Novel findings: Expression of angiotensin-converting enzyme and angiotensin-converting enzyme 2 in thoracic aortic dissection and aneurysm[J]. Journal of the reninangiotensin-aldosterone system: JRAAS, 2015, 16(4):1130.

2. Li Y, Zhang E, Wu Z. The polymorphisms in angiotensin-converting enzyme and angiotensinconverting enzyme 2 are not associated with thoracic aortic diseases and coronary heart disease [J]. Proceedings of Singapore Healthcare, 2016:2010105816628541.

3. Kalay N, Caglayan O, Akkaya H, et al. The Deletion Polymorphism of the Angiotensin-Converting Enzyme Gene Is Associated with Acute Aortic Dissection [J]. Tohoku Journal of Experimental Medicine, 2009, 219(1):33.

4. Chen J, Lei Z, Liu C, et al. Discussion on the Selection of ACEI and ARB for the Patients with COVID19 and Hypertension from ACE2 [J]. Medicinal Plant, 2020(4).

5. Yao Y, Wang H, Liu Z. Expression of ACE2 in airways: Implication for COVID-19 risk and disease management in patients with chronic inflammatory respiratory diseases[J]. Clinical \& Experimental Allergy, 2020, 50(12).

6. Zhang Z, Guo L, Huang L, et al. Distinct disease severity between children and older adults with COVID-19: Impacts of ACE2 expression, distribution, and lung progenitor cells [J]. Clinical Infectious Diseases, 2021.

7. Takeuchi S, Yamaguchi Y, Soejima K, et al. Incidence and characteristics of acute aortic dissection in patients with out-of-hospital cardiopulmonary arrest evaluated by non-contrast computed tomography [J]. European Heart Journal: Acute Cardiovascular Care, 2020:204887262092364.

8. Sinha S, Sehgal A, Sehgal R. Association of ACE2 receptor and ACEIs/ARBs with disease severity in COVID-19[J]. Drug Discoveries \& Therapeutics, 2020, 14(4):161-170. 
9. Kochergin N A, Kochergina A M, Ganiukov V I. Predictors of acute coronary syndrome in patients with ischaemic heart disease [J]. Angiologii囚a i sosudistai囚a khirurgii囚a = Angiology and vascular surgery, 2020, 26(3):179.

10. Xu F, Gao J, Munkhsaikhan U, et al. The Genetic Dissection of Ace2 Expression Variation in the Heart of Murine Genetic Reference Population [J]. Frontiers in Cardiovascular Medicine, 2020, 7.

11. Lu H, Rateri $D$, Bruemmer $D$, et al. Involvement of the renin-angiotensin system in abdominal and thoracic aortic aneurysms[J]. Clinical Science, 2012, 123(9):531.

12. Takata $\mathrm{H}$, Yamada $\mathrm{H}$, Kawahito $\mathrm{H}$, et al. Vascular angiotensin II type 2 receptor attenuates atherosclerosis via a kinin/NO-dependent mechanism[J]. Journal of the renin-angiotensinaldosterone system: JRAAS, 2013, 16(2).

13. Kuba K, Imai Y , Penninger J M . Multiple functions of angiotensin-converting enzyme 2 and its relevance in cardiovascular diseases.[J]. Circulation Journal, 2013, 77(2):301-308.

14. Elefteriades J A, Pomianowski P. Practical genetics of thoracic aortic aneurysm.[J]. Progress in Cardiovascular Diseases, 2013, 56(1):57-67.

15. Cassis $L A$, Gupte $M$, Thayer $S$, et al. Angiotensin II infusion promotes abdominal aortic aneurysms indepednent of increased blood pressure in hypercholesterolemic mice[J]. Ajp Heart \& Circulatory Physiology, 2009, 296(5):H1660-H1665.

16. El-Hamamsy I, Yacoub M H. Cellular and molecular mechanisms of thoracic aortic aneurysms.[J]. Nature Reviews Cardiology, 2009, 6(12):771-786.

17. Macura K J , Corl F M , Fishman E K, et al. Pathogenesis in acute aortic syndromes: aortic dissection, intramural hematoma, and penetrating atherosclerotic aortic ulcer.[J]. Ajr Am J Roentgenol, 2003, 181(2):309-316.

18. Crackower M A, Sarao R, Oudit G Y, et al. Angiotensin-converting enzyme 2 is an essential regulator of heart function.[J]. Nature, 2002, 417(6891):822-8.

19. Ohshima K, Mogi M, Nakaoka H, et al. Possible Role of Angiotensin-Converting Enzyme 2 and Activation of Angiotensin II Type 2 Receptor by Angiotensin-(1-7) in Improvement of Vascular Remodeling by Angiotensin II Type 1 Receptor Blockade[J]. Hypertension, 2014, 63(3):e53.

\section{Tables}

\section{Table 1: Clinical data of the patients}




\begin{tabular}{|lllll|}
\hline Clinical Data & $\mathrm{AD}(\mathrm{n}=34)$ & $\mathrm{CHD}(\mathrm{n}=21)$ & Control Group $(\mathrm{n}=13)$ & P-Value \\
\hline Age $($ Years $)$ & $54 \pm 12$ & $65 \pm 6$ & $49 \pm 13$ & 0.203 \\
\hline Male & 27 & 19 & 10 & 0.629 \\
\hline Smoking & 14 & 9 & 5 & 0.989 \\
\hline BP & 25 & 12 & NA & 0.107 \\
\hline DM & 2 & 5 & NA & 0.158 \\
\hline Diameter of AA & $59 \pm 4$ & $30 \pm 2$ & $29 \pm 2$ & $<0.001$ \\
\hline
\end{tabular}

Table 2: ACE, ACE2 and $\beta$ actin gene primer sequences and PCR amplification products

\begin{tabular}{|c|c|c|}
\hline Gene & $5, .3$, Sequence & Length \\
\hline \multirow[t]{2}{*}{ ACE } & FУ 5 ,.ТССТСАСТСАТСАСССТСАС. 3 , & $129 \mathrm{bp}$ \\
\hline & RУ 5 ,.ТСТTССТССТСТСТСТССТС.3 , & \\
\hline \multirow[t]{2}{*}{ ACE2 } & FУ 5 ,.САТТССАССААСТСТТССАТСТТ.3 , & $108 \mathrm{bp}$ \\
\hline & R囚 5 ,.САССТААТССАТСССАТТСТСА. 3 & \\
\hline \multirow[t]{2}{*}{ B.actin } & FУ 5, ,АСТАТССССААТСАССССТТС. 3 , & 77 bp \\
\hline & $\mathrm{R} \rrbracket 5$,.АТСССАСАССАТТССАТАССС. 3 , & \\
\hline
\end{tabular}

